\title{
Can Acculturation Lead To Language Death? A Case Study
}

\author{
Dr. Rajeev K. Doley \\ Training \& Placement Cell, Tezpur University, Assam, India
}

\begin{abstract}
Many of the societies today are multicultural and multilingual. This stage is usually preceded by a long process of acculturation where elements of the dominant culture or language flow to the minority culture or language leading to its distortion and in some cases even displacement and subsequent death. The present paper examines this aspect of acculturation taking the case of the Misings of the Brahmaputra valley as a case study. This originally hill dwelling tribal group is highly bicultural and bilingual today following an eighthundred-year long acculturation with the plains people of the valley. Factors like education and an increasing trend of urbanization of the group have led to the fear of a possible displacement of the Mising language in the distant future. Keeping these aspects in mind, data have been collected and analyzed in the light of Matthias Brenzinger's model (1997). Although this group has been massively acculturated, a number of its original cultural and linguistic traits also are active in their belief and behaviour suggesting that it has not altogether shunned its original culture while accepting the contact culture. However, a continuous increase in the number of children brought up and educated in cities loom as a threat.
\end{abstract}

Key Words : Acculturation, code-switching, language death, Misings.

\section{Introduction}

In a multicultural society, socio-cultural intermixing amongst the members of various ethnic groups living together is a common phenomenon. With the proliferation of the communication system today, behavioural plurality is crossing the boundaries of societies affecting a large chunk of people across the globe. Over the centuries, societies the world over have seen how the practices of their members have changed culturally and linguistically. Although imitation and adoption are parts of common human nature, normally, members of a socially and culturally less dominant group tend to be attracted towards the cultural practices of the dominant group and this tendency in course of time leads to their adoption and practice by the members of the minority group. This cross-cultural passage called acculturation may lead to a syncretism and, in some cases, it may even lead to the replacement of the minority culture causing death to its cultural heritage including language. The present paper examines the various stages of language death through the process of acculturation vis-à-vis the case of the Misings of the Brahmaputra valley. This tribal group of Assam settled in the valley during the thirteenth - fourteenth century AD after migrating down from the hills of the present Arunachal Pradesh. Now the members of this group are highly bicultural and bilingual and the cross-cultural elements are still flowing in. This has prompted some scholars to believe that the process, if continued in the rising trend, may pose threat to the cultural and linguistic heritage of the group. The paper focuses on the affect of acculturation on the Mising language and attempts to find out the eventualities of a continued and increasing practice of bilingualism.

\section{Definitions and Scope}

Social scientists and researchers have defined 'acculturation' in various terms. According to Redfield, Linton and Herskovits (1936), "Acculturation comprehends those phenomena which result when groups of individuals having different cultures come into continuous first-hand contact, with subsequent changes in the original culture patterns of either or both groups". Robert H. Winthrop (1991) adds that it is the "process of systematic cultural change of a particular society carried out by an alien, dominant society". Acculturation is a gradual process and comprises those changes in a culture brought about by another culture which result in an increased similarity between the two cultures. Here, A.L. Kroeber (1948) states, "This type of change may be reciprocal, however, very often the process is asymmetrical and the result is the (usually partial) absorption of one culture into the other." From the above definitions, it is understood that acculturation involves cultural and behavioural changes in the affected group(s) resulting in a massive shift of interest from the indigenous culture to the new culture. However, although the process of acculturation causes massive changes to the old culture, it does not necessarily mean that it replaces the indigenous culture in entirety. In this regard, Dennis O'Neil (2006) says, "There often is a syncretism or an amalgamation of traditional and introduced traits. The new traits may be blended with or worked into the indigenous culture to make them more acceptable". In the light of this 
elucidation, the present work deals with the various stages of cultural change in respect of the Misings living mostly in the upper half of the Brahmaputra valley of Assam.

\section{A Look at the Previous Works}

A number of articles and essays have been written on Mising culture and language and published in popular magazines, souvenirs and compiled works, but research based empirical studies have rarely been carried out on the subject. The most important work on Mising history, culture and language is Bhrigumoni Kagyung's compiled work "Mising Sanskritir Alekhya" written in Assamese and published in 1989. This collection has essays written by eminent writers and scholars on Mising culture and language till the end of 1980s. Another collection titled "The Misings : Their History and Culture" edited and brought out by Dr. J.J. Kuli came out in 1998. This book also contains essays and articles on Mising cultural traditions and their continuity and acculturation. In 2000 Dr. N.C. Pegu brought out a book titled "Mising Hakalar Itibrita Aru Sanskriti" in Assamese outlining the history and culture of the Misings of the contemporary period. However, a research based pragmatic study will put the arguments more authentic and hence is the present paper.

\section{The Target Group Misings}

The Misings (exonym Miri) are one of the major ethnic groups of Assam in the north-east India and they form the second largest tribe of the state after the Bodos. According to the 2001 census, the population of the Misings in Assam was 5,87,310 which constituted more than 17.8\% of the total tribal population of the state. Of this, $88 \%(5,17,170)$ are speakers of the Mising language and the rest $12 \%$ have gradually switched to Assamese in the process of their acculturation in the Brahmaputra valley (Taid, 2010: 4). The literacy rate of the Misings, according to the same source, was $60.1 \%$ (male $71.4 \%$ and female $48.3 \%$ ). However, a survey conducted in 2006 by a non governmental organization Native Planet put the Mising population at 12,57,596 living in 1724 scheduled villages. The Mising population is found in the upper half of Assam spreading over the districts of Dhemaji, Lakhimpur, and Sonitpur in the North Bank and Tinsukia, Dibrugarh, Sibsagar, Jorhat, and Golaghat in the south bank of the Brahmaputra. A sizable Mising population is found in the eastern districts of Arunachal Pradesh also. With the proliferation of education among the Misings and a good number of them being inducted to government and public jobs, a large number has settled in cities like Guwahati, Jorhat, Dibrugarh, Sibsagar, Dibrugarh, Tinsukia, Tezpur, North Lakhimpur, Dhemaji and other towns of Assam; as well as Pasighat, Oyan and a few other towns in Arunachal Pradesh.

Historians and researchers believe that the Misings migrated from the upper courses of the rivers Huang-Ho and Yangtse-Kiang in North-west China and entered India around 2000 B.C. and finally landed in the Brahmaputra valley between the thirteenth century and the fourteenth century A.D. (Pegu, Nomal 1998, 34).

\section{The Acculturation and the Mising Language}

As the theory goes, in a bicultural or multicultural society, elements of the dominant culture flow to the minority culture(s). In course of time, this process, if continued in the ascending order, may lead to shift or displacement or even extinction of the minority culture(s). The practice of code-switching from Mising to Assamese by the Misings of Assam is centuries old and remarkably deep-rooted. Now what is to be seen is the future of the Mising language in view of this language behaviour of its speakers. According to Doley (2008), while making an oral expression in the first language (L1), the Misings on an average use $35 \%$ Assamese words, $7 \%$ English words and 1.5\% words from Hindi or other languages. This percentage increases to $57 \%, 18 \%$ and $3 \%$ respectively in case of the educated and the city/town dwellers leaving just $22 \%$ for their ethnic language, i.e., Mising. But this group constitutes just $13 \%$ of the total Mising population and the rest $87 \%$ uses their ethnic language which dominates their speech elements roughly by $78 \%$ on an average. Therefore, the interlingual code-switching is more frequent with the educated and city dwellers than it is with the ruralites comprising illiterates or semiliterates. Here two points are noteworthy : (a) parents in general are more interested in putting their children in urban schools and colleges, and (b) there is an upward trend in the general interest level of the rural people, particularly those financially sound, in migrating and settling in urban areas. From these observations, it is evident that the bilingual practice among the Misings is steady in its upward trend.

Will this trend lead to a shift or displacement of the Mising language in future? It will be worthwhile to take a look at its present scenario and the future possibilities.

\section{V.1 The world Scenario}

Before we go into assessing the future possibilities of the Mising language, let us cast a glance at the world scenario on language shift. In this regard, Matthias Brenzenger $(1997,273)$ observes, "In all parts of the world, we observe an increasing tendency among members of ethnolinguistic minorities to bring up their children in a language other than their own mother tongue, thereby abandoning their former ethnic languages. 
These changes in language use by individuals might ultimately lead to the irreversible disappearance of the minority's original language." The domination of a few languages worldwide and the high speed spread of such languages through modern communication, dominant economy, colonization, and dominant political and military power have contributed to their supremacy over the lesser languages. Although there is a disagreement among the researchers on displacement of world languages, some scholars have put forward interesting statements. According to an estimate given by Hill $(1978,69)$, in the last 500 years, at least half of the world languages have disappeared, and another scholar Krauss (1992) states that only 10 percent of the present languages of the world are "safe" and therefore not threatened by future extinction. However, researchers dispute over the subject of language extinction. Some scholars state that weaker languages may get displaced or assimilated to another stronger language but will not die, while others say that language displacement do not take place at a large scale and only a few languages in the world are threatened by extinction.

\section{V.2 The Stages of Language Shift}

Language shift is a long process. "The process of language displacement takes at least three generations. This is not a unidirectional development, but in the course of time successive phases with different characteristics modify the process before a language becomes extinct." (Brenzinger 1997, 282). The process takes place mainly in three phases :

Phase I - Initial intercultural contacts take place.

Phase II - As attracted by its wider exposure and stronger competence, the children of the minority ethnolinguistic group are educated through the majority language.

Phase III - Gradually, interpersonal and intergroup communications take place more in the majority language for which the bilingualism develops into a monolingualism in the stronger language. Recessive use of the minority language leads to the process of its shift or displacement which might finally lead to its extinction.

\section{V.3 Trend of the Mising Language}

In the light of the above parameters, we may now take the case of the Mising language - its present scenario, direction and future. The Mising tribe has been in contact with the plains people of the Assam valley for about 800 years. For a considerable length of time the Misings did not yield socio-cultural or linguistic cross-over from the stronger plains society. But as the contacts continued in an ever-increasing spectrum of social and occupational activities, the dominant culture found its way into the minority ethnic group. The flow reached and affected almost all fields, such as, social life, cultural pursuance, and religious belief. All these changes gave a new dimension to the linguistic behaviour of this group. A large number of elements flowed from the Assamese language to the Mising dialect resulting in the emergence of a bilingual speech among the Misings. The bilingualism or biculturalism gripped this tribe for at least six centuries, i.e., from the $14^{\text {th }}$ century to the $19^{\text {th }}$ century. When the Assam region came under the British rule after the Yandaboo Treaty of 1826, the medium of communication in the administrative set up came to be English which proved to be the dominant language over all other local languages of the region. Accordingly, another cross-cultural transmission took place with elements of the dominant British culture flowing into the local cultures. The process added elements of a third culture to the Misings. The achievement of independence by India in 1947 and the change over of power from the British to the Indians, did not bring much immediate changes to the cultural practices of the rural people in the north eastern region of the country particularly in the field of language practice. The $20^{\text {th }}$ century witnessed a significant rise in the use of the English language by the people of the Brahmaputra valley triggered by the modern system of education and the proliferation of electronic media like the radio and the television. The increase which still has an upward trend has encompassed the rural areas as well. This has added a third language to the repertoire of the Misings. After adoption of Hindi as the national language of India and the various schemes adopted by the Government of India to popularize Hindi and encourage its use, a good number of Mising students study Hindi and can speak the language with a broken accent. Although, generally they are not fluent English or Hindi speakers, they use English and Hindi words, phonemes and clauses in course of their discourse.

\section{Discussion}

There are two opposing trends found prevalent in the Mising society with respect to the Mising language. A sense of self identity and loyalty triggered by a fear of loss of ethnolinguistic identity awakened some of the enlightened Misings to begin a sort of study on and about the Mising language and culture in the mid $20^{\text {th }}$ century. With the establishment of the Mising Agom Kebang (Mising Language Society) in April, 1972 , this awakening took a revolutionary turn in speaking, writing and shaping the language. Now it has its script and the language began to be taught in Mising dominated areas at the Primary level from October, 1986. The new awakening with respect to their language and culture has revolutionized the Mising minds. As a result, innumerable writings in Mising and in other languages like Assamese and English on Mising subjects have 
appeared and new creative as well as critical works are increasingly appearing from the Mising intelligentsia. These observations suggest that the language is under a growth process and therefore does not face the threat of displacement or extinction for the next six decades given the growth trend is steady.

On the other hand, there is an increasing tendency among the Mising parents, particularly city/town dwellers, to put their children into English medium schools, being attracted by the high academic competence and popularity of the English language. This is true with other parents also in the region. These children and also those studying in Assamese medium schools in cities/towns, do not get an opportunity to learn their ethnic language in schools or from the environment. Such persons if multiplied over generations and surpass those in the rural areas, may lead to non-use of the ethnic language and therefore its gradual disappearance.

As far as the degree of mastery on both the languages is concerned, the Mising-Assamese bilingualism or code-switching is not like those in Europe or the U.S.A., such as, English-French or German-English or Finnish-Swedish. In those countries, bilingualism means proficiency in both the languages and the speaker can make his/her expressions in both the languages comfortably. This group of bilinguals has been named as 'equilinguals' or 'balanced bilinguals' (Edwards 1994, 57). The Mising-Assamese bilingualism on the other hand, in most cases, can be called 'non-fluent' or 'semi-fluent' bilingualism where the speakers switch over to the second language (L2) as a matter of habit or to find a more representing word or mode of expression. There are, of course, a few Mising people who are almost equally proficient in both the languages, but they too have to switch over to L2 when they come to technical expressions because Mising equivalents are unavailable for making such expressions. Such switches are resorted to mainly to fill lexical and expressional gaps. In some cases, the switching is found to be an intentional act through which the speaker tries to fulfill certain communicative purposes such as to include or exclude a non-speaker from an ongoing discussion.

In case of the use of the second and the third languages, there is a vast difference between the people living in the rural areas and those living in towns and cities. While Mising is the base language for the people living in the rural areas, which forms $75 \%$ of their speech elements, it is the Assamese which determines the grammatical features of the speeches of the urban people with $85 \%$ of the speech elements.

Although the Mising language does not face any threat of shift or displacement in the near future, a steady increase in urbanization of the Mising population or urban children being brought up in the present way might lead to a recession in use of the ethnic language in the distant future. It is already a common practice that just the beginning and the conclusion are spoken in Mising in formal occasions like meetings, all the body of the speech is spoken in Assamese with English words and sentences in between. This is more prevalent amongst the educated and the town dwellers. A far-reaching language policy and a systematic teaching of the ethnic language to the non-speaking children at the family level as well as at the community level, particularly in the urban areas, will keep the Mising language in a safer position.

\section{Concluding Remark}

Learning and using a language by its speakers is necessary for its survival but making others learn and use it makes the language richer and wider in its periphery. Necessary measures may be initiated by the concerned authorities/organizations so that the use of the language can be extended to the non-speakers. Initially, efforts may be made with the neighbouring non-speakers with whom cultural relations have already been established. This will enable a similar code-switching from the dominant language to the minority language, in the present case, Assamese to Mising, resulting in a European-like bilingualism.

\section{References}

[1] Redfield, R., R. Linton, and M. Herskovits, Memorandum on the study of acculturation American Anthropologist 38, 1936, 149152.

[2] Winthrop, Robert H., Dictionary of Concepts in Cultural Anthropology (Greenwood 3, New York, 1991, 82-83).

[3] Kroeber, A. L., Anthropology : Race, Language, Culture, Psychology, Prehistory (Harcourt, Brace \& World Inc., New York and Burlingame, 1948).

[4] O'Neil, Dennis (2006) Acculturation : Part I. http://anthro.palomar.edu/change/change_3.htm Accessed on February 25, 2013.

[5] Taid, T.R., Mising Gompir Kumsung (A Dictionary of the Mising Lanugage) (Anundoram Borooah Institute of Language, Art \& Cuture, Guwahati, 2010, 4).

[6] Pegu, Nomal Chandra, The Mishings, a colourful tribe of the Brahmaputra Valley, in J.J. Kuli (Ed.) The Mishings : Their History and Culture, Ayir Publications, Guwahati, 1998, 34).

[7] Doley, Rajeev K., Interlingual Code-Switching as a Sociolinguistic Phenomenon amongst the Misings of the Brahmaputra Valley (IIT Guwahati, 2008), 144.

[8] Brenzinger, Matthias, Language Contact and Language Displacement, in Florian Coulmas (Ed.) The Handbook of Sociolinguistics (Oxford : Blackwell Publishers Ltd. 1997). 273, 282.

[9] Hill, J. H., Language death, language contact and language evolution, in W.C. McCormack and Stephen A. Wurm (Eds.) Approaches to Language : Anthropological Issues, 16 (The Hague : Mouton 1978) 45-78.

[10] Krauss, M. A Broad Outline to the Language Endangerment Problem 16, CIPSH/UNESCO 1992.

[11] Edwards, John, Multilingualism, (London Penguin Books Ltd., 1994). 56, 58. 